\title{
Expression and physiology of performance regulating genes in transgenic sheep
}

\author{
C. D. Nancarrow, J. T. A. Marshall, J. L. Clarkson, J. D. Murray†, \\ R. M. Millard*, C. M. Shanahan, P. C. Wynn and K. A. Ward \\ CSIRO Division of Animal Production, P.O. Box 239, Blacktown, NSW 2148, Australia; and \\ * Macquarie Pathology Services, 35 Moore St, Leichhardt, NSW 2040, Australia
}

Keywords: growth hormone; transgenic sheep; pituitary; lipids; reproduction; metabolic hormones

\section{Introduction}

The potential of man to alter the genome of animals by means other than classical breeding was realized around a decade ago. Gordon et al. (1980) and Costantini \& Lacy (1981) reported on the ability of DNA, injected into one of the pronuclei of mouse embryos, to enter and become stably integrated into the genome. This work demonstrated how livestock productivity might be improved drastically by the introduction of appropriate homogeneic or xenogeneic fusion genes developed in the laboratory. This method could create new genetic combinations resulting either in expression of important proteins in quantities that can be harvested, for example from milk, or in modification of physiology such that livestock can be produced more efficiently or with altered characteristics. This latter possibility was dramatically demonstrated by Palmiter et al. (1982) who showed that growth of mice responded to zinc induction of an incorporated mouse metallothionein-rat growth hormone (mMt-rGH) fusion gene. Production of the first transgenic sheep and pigs was reported by Hammer et al. (1985b) who used a mMt-human GH (mMt-hGH) fusion gene construct. Subsequently, physiological abnormalities resulted from the uncontrolled expression of the $\mathrm{GH}$ gene (Pursel et al., 1987, 1989; Rexroad et al., 1989), and this exemplified the largely empirical nature of these studies based on inadequate knowledge concerning physiological processes regulating production.

Since 1985 there have been few genes successfully integrated into sheep and none has yet proved to be of benefit to the livestock industry. Attempts to modify milk protein production utilizing B-lactoglobulin promoter fusion genes appear to suffer from under-expression (Simons et al., 1988; Clark et al., 1989). The use of transgenic sheep to produce proteins such as human anti-haemophilic Factor IX and human $\alpha$-antitrypsin for the pharmaceutical industry are not expected to alter the basic physiology of sheep and will not be considered here.

Transgenic sheep and pigs carrying a fusion gene based on various $\mathrm{GH}$ genes represent the major performance regulating genes that have been reported to alter significantly the physiology of their carriers. The genes used at the Beltsville laboratory (Hammer et al, 1985b, 1986; Pursel et al., 1987; Rexroad et al., 1989) have been constructed from mouse Mt promoters using GH sequences taken from human and bovine sources. The other gene used, human GH-releasing factor, also caused overproduction of endogenous pituitary-derived $\mathrm{GH}$ and this resulted in physiological effects similar to those caused by the GH transgenes (Hammer et al., 1985a; Rexroad et al., 1989). From our laboratory, Murray et al. (1989) reported the production of transgenic sheep using sheep metallothionein la-sheep GH fusion genes (sMt-sGH, the MtsGH-series). In this paper, we report 
on the physiological effects of this gene construct in transgenic sheep and highlight important biochemical processes that should be examined in future work. Some results from this work have been published previously (Nancarrow et al., 1988a, b, 1989; Ward et al., 1990).

\section{Production and husbandry}

Embryo manipulation. The methods of embryo production and pronuclear microinjection used for generating transgenic Merino sheep in this laboratory have been described fully by Murray el al. (1989). A summary of success rates in domestic livestock has been published by Rexroad \& Pursel (1988) and this shows that the survival rates of injected and transferred embryos vary from 3 to $29 \%$ and the production rates of transgenic offspring vary from 0 to $2 \cdot 07 \%$. Recently, we have transferred 3-4 injected embryos to oviducts in 1 or $2 \mu 1$ washing medium using a Drummond Micropipette (Drummond Scientific Co., Broomall, PA, USA), The pregnancy rate increased in recipients from $20-30 \%$ to $50 \%$ and the percentage of injected, transferred embryos producing lambs from 5-10\% to $13 \%$.

Diets. Transgenic sheep were kept in group pens with their dams and fed ad libitum sheep pellets consisting of a 60:40 mixture of lucerne chaff and crushed oats. After weaning, ewe lambs were fed ad libitum high-protein CCK pellets (60:40 pellets including 5\% (w/w) fish meal). In an attempt to control expression of the fusion gene by decreasing the plasma concentration of zinc, a diet containing < 5 p.p.m. zinc (Dr B. Purser, CSIRO Division of Animal Production, Floreat Park, WA, Australia) was fed at 100 and 213 days of age for short periods of time. As this diet was unpalatable, the lambs were not offered it for more than a 2 -week period as an adequate nutrient intake could not be maintained. Lambs were bled daily throughout this treatment.

The male transgenic and 3 control lambs were fed ad libitum 60:40 pellets after weaning, with one of the controls being pair-fed 1 day in arrears.

Zinc treatments. Sucking Merino ewe lambs (4-11 kg), approximately 4 weeks old, were housed in indoor pens. Lambs were placed in two experimental groups each containing 1 transgenic lamb and 2 control lambs. Lambs in both groups were dosed intramuscularly with zinc $(15 \mathrm{mg} / \mathrm{kg})$ given as an emulsion ( $40 \mathrm{mg}$ zinc metallic dust/ml incomplete Freund's adjuvant:saline, 1:1 emulsion) at 4 weeks of age. Lambs in the second group were given a second dose when 5 weeks old. Lambs were bled at $0,8,24,48$ and $72 \mathrm{~h}$, and then weekly, and the plasma separated and stored at $-20^{\circ} \mathrm{C}$.

Sampling of lambs. Lambs were bled within 3 days of birth, then at 1-week intervals thereafter until death. Short-term patterns of hormone secretion were determined for control and transgenic lambs from blood samples collected through a catheterized jugular vein at 20 -min intervals for a period of $26 \mathrm{~h}$. These samples were divided into 3 aliquots, 2 with heparin and 1 with EDTA added as anticoagulants. Blood plasma was separated and stored at $-20 \mathrm{C}$.

Pituitary and testicular functions in the male transgenic and 3 control male lambs were tested by injecting $250 \mu \mathrm{g}$ gonadotrophin-releasing hormone $(\mathrm{GnRH}$, Sigma Chemical Co., St Louis, MO, USA) in $0.5 \mathrm{ml}$ saline, through the jugular catheter, at the end of the $26-\mathrm{h}$ bleeding period and sampling the blood for a further $4 \mathrm{~h}$.

Tissue sampling. At death, the animals were dissected as soon as possible, tissues were weighed and samples either frozen in liquid nitrogen for assessment of gene expression or preserved in fixative for histological examination at a later date. Complete sets of tissues could not be collected from all lambs.

\section{Gene construction and expression}

\section{Construction of genes}

Transgenic lambs have been produced from each of 3 fusion gene constructs based on the sheep $\mathrm{GH}$ genomic sequence, including the entire GH 3 -non-coding sequence. The construction of 
MtsGH5 and MtsGH9 has been described previously (Nancarrow et al., 1988b; Murray et al., 1989; Shanahan et al., 1989) and all consist basically of a promoter sequence for sheep metallothionein 1a, of 861 base pairs (bp), fused to the $3.9 \mathrm{~kb} \mathrm{GH}$ sequence (MtsGH9). MtsGH5 and MtsGH10 have an additional 500 bp sequence from the SV40 viral origin of replication fused to the $3^{\prime}$ end of the GH genomic sequence. MtsGH5 also differs from MtsGH 10 and MtsGH9 in that the spacing between the promoter and the GH gene has an additional $300 \mathrm{bp}$ sequence.

\section{Transgenics and expression}

We have produced $4 \mathrm{MtsGH} 5,4 \mathrm{MtsGH} 9$ and $1 \mathrm{MtsGH} 10$ lambs. The fusion gene was not expressed in any of the MtsGH5 (Nancarrow et al, 1988b; Murray et al., 1989) or MtsGH10 lambs; all remain alive and transmit the gene to their offspring. The MtsGH5 founder sheep have produced 5 transgenic sheep from 13 offspring and MtsGH10 founder sheep 4 from 5 . None of the MtsGH5 offspring express GH. The MtsGHI0 offspring have yet to be tested.

All 4 MtsGH9 lambs expressed GH constitutively at high levels (Fig. 1) and all died before 1 year of life. The ewe lamb (No. 548) died at 62 days from a presumptive kidney infection. The bulk of this paper, however, describes experiments and observations concerning the physiology of the remaining $3 \mathrm{MtsGH} 9$ sheep, 2 ewe lambs (Nos 3905 and 3906) and $1 \mathrm{ram}$ lamb (No. 5442).

\section{Tissue expression and zinc induction}

The sheep Mt la promoter was previously shown to function in transgenic MtsGH9 mice with its expression controlled by zinc dosage (Shanahan et al., 1989). Basal expression, noted in mouse brain and testis, was not further induced by zinc treatment. However, expression in the small intestine, kidney and liver was significantly increased by providing $25 \mathrm{~mm}$-zinc in the drinking water. These 3 tissues also synthesized mRNA during the suckling period, an observation that reflects the high zinc content of colostrum and milk.

The major sites of constitutive expression in sheep were the liver, kidney, brain and hypothalamus (Ward et al, 1990) and these tissues broadly corresponded with the pattern of expression in mice. However MtsGH9 was found to express GH in sheep without additional zinc treatment (Fig. 1)

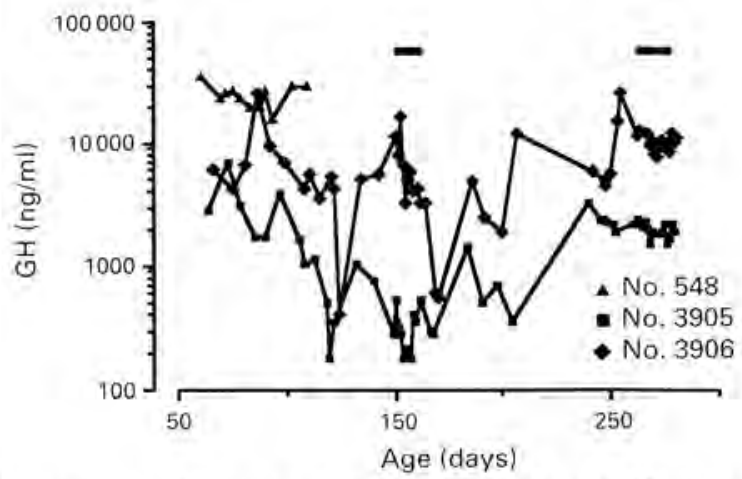

Fig. 1. Growth hormone concentrations in transgenic ewe lambs. Weaning occurred at 77-80 days of age. Periods of feeding a zinc-deficient diet are indicated by horizontal bars.

The MtsGH5 construct could not be induced to express in either mice or sheep. However, the modification, MtsGH10, expressed constitutively in mice (N. Rigby, personal communication) but no expression of mRNA was detected in a biopsy of liver of the transgenic male lamb even after zinc treatment.

\section{Zinc levels in plasma}

The concentrations of zinc, iron and copper in lamb plasma diluted 1:10 with distilled water were estimated using an Atomic Absorption Spectrophotometer (Varian Techtron AA6, Varian, 
North Springvale, Victoria, Australia). Zinc concentrations in plasma were used to monitor direct effects of zinc treatments and dietary changes and iron and copper were used to detect whether there were any effects of zinc treatments or high concentrations of $\mathrm{GH}$ on other metal ions in plasma. Zinc concentrations fluctuated widely, with values over $300 \mu \mathrm{g} / \mathrm{ml}$ associated with the early suckling period. Basal levels of $50-100 \mu \mathrm{g} / 100 \mathrm{ml}$ were reached about the time of weaning (77-80 days). There were no differences between controls and transgenics and injecting zinc dust had no appreciable long-term effect on these levels. Feeding the zinc deficient diet decreased the plasma zinc concentrations but not below levels found occasionally $(30 \mu \mathrm{g} / 100 \mathrm{ml})$. No obvious differences were found for plasma concentrations of total iron or copper between control and transgenic lambs or in response to zinc or dietary treatments.

\section{Growth hormone}

The patterns of GH found in plasma of the 3 MtsGH9 ewe lambs for most of their life are shown in Fig. 1. Concentrations of GH were extremely high, particularly for No. 548 that died early. Generally, plasma concentrations varied greatly throughout life, from 400 to $26000 \mathrm{ng} / \mathrm{ml}$ for No. 3906, for example. Highest values were obtained for all lambs at or soon after birth (see also Rexroad et al., 1989) and while these appear to coincide with high plasma zinc levels and to reflect the mechanism of milk induction as seen in mice, similar high values were also found later in life. There was an indication that GH concentrations decreased in response to the first period of a low-zinc diet, particularly in No. 3906 (Fig. 1) but, when the treatment was repeated, $\mathrm{GH}$ levels remained stable, despite zinc concentrations reaching as low as $35 \mu \mathrm{g} / 100 \mathrm{ml}$ for several days.

\section{Growth rates}

The growth rates of 3 of the $4 \mathrm{MtsGH} 9$ sheep were not different from their controls (Fig. 2). Episodes of low dietary intake were reflected as slight falls in bodyweight. As their health deteriorated, the transgenic sheep lost condition and their growth curves abruptly fell below those of the controls. The growth rate of lamb No. 3906 remained considerably less than the growth rates of the other lambs. This lamb failed to gain weight during its first weeks of life and the presence of abnormally high levels of AST, CPK, LDH and ALT activities in its plasma, all with maximum values at 49 days of age, indicated that it had suffered from some form of debilitating pathological stress.
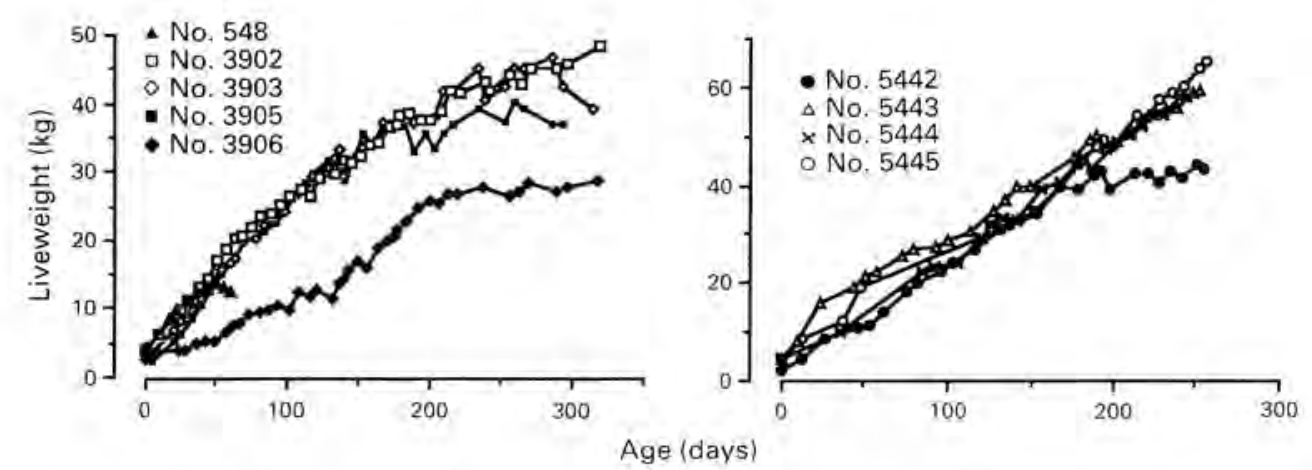

Fig. 2. Liveweight increases in transgenic and control lambs. Filled symbols represent transgenic lambs, open symbols control lambs. 


\section{Hormonal status and metabolic rate}

\section{Hormone assays}

GH assay has been described previously by Murray et al. (1989), Dilution of samples several hundred-fold with plasma from hypophysectomized sheep was necessary to obtain values within the range of the standard curve. The values presented here, and previously, are therefore not absolute, but as serial dilution of plasma from these transgenic lambs or from fetal lambs $(40-100 \mathrm{ng} / \mathrm{ml})$ produced curves which displayed parallelism to the standard curve, we have confidence in their representation of events in vivo.

Plasma insulin was measured with a standard double-antibody radioimmunoassay procedure. Where necessary, plasma samples were diluted with assay buffer so that concentrations were within the standard curve.

Insulin-like growth factor-1 (IGF-1) was measured by a double antibody radioimmunoassay (Owens et al., 1990) using recombinant IGF-1 supplied by Dr B. D. Burleigh, International Minerals and Chemical Corporation (Northbrook, IL, USA) as the standard. Before assay, plasma samples were precipitated with acid ethanol (Daughaday et al., 1982) and the supernatants acid-chromatographed (Owens et al., 1990) to separate IGF-1 from its plasma binding proteins.

Prolactin, luteinizing hormone ( $\mathrm{LH}$ ), follicle-stimulating hormone (FSH), thyroxine, triiodothyronine (T3), testosterone and progesterone were all estimated by standard radioimmunoassay techniques used in this laboratory.

\section{Growth hormone, insulin, IGF-1 and glucose}

Plasma samples taken over a $26-\mathrm{h}$ period showed that $\mathrm{GH}$ was released in a pulsatile fashion from the pituitary of control animals, reaching concentrations of between 10 and $30 \mathrm{ng} / \mathrm{ml}$ plasma from zero basal levels. The secretion of $\mathrm{GH}$ in all the transgenic lambs was also pulsatile in nature, despite the fact that circulating levels were several thousand-fold higher than those observed in controls (Table 1) and that studies of tissue expression indicated that most of the GH was released from organs other than the anterior pituitary gland. No circadian rhythms were found.

Plasma insulin concentrations, measured on the same blood samples, showed a distinct diurnal rhythm in control animals that was entrained to the time of once-daily feeding. By contrast, no such rhythm was observed in any of the transgenic animals. The values for insulin (Table 1) were in fact normal when averaged over the 26 -h period for the female lambs but were elevated for No. 5442. However, there were several episodes of excessive insulin secretion in all the transgenic lambs, apparently in response to elevated glucose levels, which occurred throughout their life. Hence insulin concentrations were found to be significantly higher in the long-term study of these lambs.

Plasma GH and IGF-1 concentrations were also measured on 3 blood samples taken from each of the transgenic lambs and 3 control lambs (Table 2). Concentrations of IGF-1 are normally higher in the male and we have confirmed this here. The higher circulating concentrations of GH in the transgenic lambs caused a 2-4-fold increase in concentrations of plasma IGF-1 to about $1000 \mathrm{ng} / \mathrm{ml}$ for both sexes. In organs which express the fusion gene, like the liver, it is probable that $\mathrm{GH}$ acts in an autocrine fashion to induce increased local production of IGF-1. Similar responses were found in transgenic pigs (Ebert et al., 1988; Miller et al., 1989; Pursel et al., 1989), transgenic mice (Palmiter et al,, 1983) and in pigs injected daily with pig GH (Owens et al., 1990). These increases in sheep, pigs and mice were of similar magnitude and lend support to the suggestion by Miller et al. (1989) that the IGF-1 response in tissues may be constrained to a similar range across species.

A major function of $\mathrm{GH}$ is its direct stimulation of glycogenolysis resulting in release of glucose into the blood; an insulin response follows and elevations in these substances have been found in 
Table 1. Hormone concentrations in blood plasma of individual control and transgenic lambs serially sampled over $26 \mathrm{~h}$ (mean \pm s.d.; $n=75-79$ )

\begin{tabular}{|c|c|c|c|c|c|c|}
\hline & & Control & & & Transgenic & \\
\hline $\begin{array}{l}\text { Sheep no. } \\
\text { Age (days) } \\
\text { Gender }\end{array}$ & $\begin{array}{c}3902 \\
289 \\
\text { F }\end{array}$ & $\begin{array}{c}3903 \\
285 \\
\mathrm{~F}\end{array}$ & $\begin{array}{c}5443 \\
146 \\
\mathrm{M}\end{array}$ & $\begin{array}{c}3905 \\
285 \\
\text { F }\end{array}$ & $\begin{array}{c}3906 \\
288 \\
\text { F }\end{array}$ & $\begin{array}{c}5442 \\
149 \\
\mathrm{M}\end{array}$ \\
\hline $\begin{array}{l}\mathrm{GH}(\mathrm{ng} / \mathrm{ml}) \\
\mathrm{FSH}(\mathrm{ng} / \mathrm{ml}) \\
\text { Prolactin }(\mathrm{ng} / \mathrm{ml}) \\
\text { Insulin }(\mathrm{ng} / \mathrm{ml}) \\
\text { Tri-iodothyronine } \\
\text { (ng } 100 \mathrm{ml} \text { ) } \\
\text { Thyroxine }(\mathrm{ng} / \mathrm{ml} \text { ) }\end{array}$ & $\begin{array}{c}2 \cdot 0 \\
111 \pm 46 \\
26 \pm 23 \\
2 \cdot 8 \pm 1 \cdot 5 \\
57 \pm 10 \\
12 \cdot 4 \pm 3 \cdot 7\end{array}$ & $\begin{aligned} & 3 \cdot 5 \\
& 164 \pm 66 \\
& 20 \pm 21 \\
& 3 \cdot 2 \pm 2 \cdot 1 \\
& 50 \pm 13 \\
& 10 \cdot 5 \pm 0 \cdot 5\end{aligned}$ & $\begin{array}{c}7 \cdot 9 \\
91 \pm 46 \\
31 \pm 23 \\
1-0 \pm 0 \cdot 6 \\
67 \pm 18 \\
6-1 \pm 2+7\end{array}$ & $\begin{aligned} 2870 & \pm 680 \\
233 & \pm 69 \\
12 & \pm 6 \\
4 \cdot 8 & \pm 0 \cdot 8 \\
25 & \pm 7 \\
6 \cdot 9 & \pm 2-1\end{aligned}$ & $\begin{array}{c}42500 \pm 18060 \\
135 \pm 38 \\
8 \cdot 4 \pm 1 \cdot 3 \\
1 \cdot 0 \pm 0 \cdot 6 \\
19 \pm 8 \\
3 \cdot 4 \pm 0 \cdot 8\end{array}$ & $\begin{aligned} 402 & \pm 93 \\
83 & \pm 33 \\
146 & \pm 56 \\
17 \cdot 2 & \pm 5 \cdot 9 \\
86 & \pm 12 \\
5 \cdot 5 & \pm 1-3\end{aligned}$ \\
\hline
\end{tabular}

Samples were taken every $20 \mathrm{~min}$ via indwelling jugular catheters.

Table 2. GH and IGF-I concentrations in blood plasma of lambs over a period of 3 weeks

\begin{tabular}{|c|c|c|c|c|c|c|}
\hline & \multicolumn{3}{|c|}{ Control } & \multicolumn{3}{|c|}{ Transgenic } \\
\hline & $\begin{array}{c}\text { No. } 3902^{*} \\
(₹)\end{array}$ & $\begin{array}{c}\text { No. } 3903^{*} \\
\text { (I) }\end{array}$ & $\begin{array}{c}\text { No. } 5443 t \\
\text { (3) }\end{array}$ & $\begin{array}{c}\text { No. } 3905^{*} \\
(\text { ( ) }\end{array}$ & $\begin{array}{c}\text { No. } 3906^{*} \\
(z)\end{array}$ & $\begin{array}{l}\text { No. } 5442 \dagger \\
\text { (s) }\end{array}$ \\
\hline $\mathrm{GH}(\mathrm{ng} / \mathrm{ml})$ & $\begin{array}{l}1 \cdot 0 \\
0 \\
1 \cdot 0\end{array}$ & $\begin{array}{l}0-5 \\
0 \\
0\end{array}$ & $\begin{array}{l}18 \\
12 \\
16\end{array}$ & $\begin{array}{l}3000 \\
1500 \\
2000\end{array}$ & $\begin{array}{r}5900 \\
25600 \\
11200\end{array}$ & $\begin{array}{l}2470 \\
5040 \\
4960\end{array}$ \\
\hline Mean & 0.7 & 0.2 & 15 & 2170 & 14230 & 4160 \\
\hline IGF-I (ng/ml) & $\begin{array}{l}270 \\
299 \\
266\end{array}$ & $\begin{array}{l}185 \\
329 \\
248\end{array}$ & $\begin{array}{l}526 \\
805 \\
615\end{array}$ & $\begin{array}{r}960 \\
1050 \\
1160\end{array}$ & $\begin{array}{r}1000 \\
640 \\
1090\end{array}$ & $\begin{array}{r}740 \\
1060 \\
1190\end{array}$ \\
\hline Mean & 275 & 254 & 616 & 1060 & 910 & 1000 \\
\hline
\end{tabular}

${ }^{*}$ Aged $188-212$ days.

tAged 80-97 days.

transgenic pigs by Ebert el al. (1988) and Pursel et al. (1989). Whether these animals die as a result of this diabetogenic effect of $\mathrm{GH}$, as suggested by us previously (Ward et al., 1990), is a matter for conjecture. Although non-fasting glucose concentrations of MtsGH9 transgenic lambs were elevated for lengthy periods during their lifetime (Table 3), insulin concentrations generally increased also, thus lowering these glucose levels temporarily (data not shown). At death, both glucose and insulin were within normal bounds for these 2 female lambs. Therefore, the suggestion by Ebert et al. (1988) that insulin resistance is responsible for death of the transgenic lambs does not seem correct here. Insulin resistance is a syndrome that occurs when the number of insulin receptors is reduced and this interferes with the reduction of glucose concentrations in blood. Measurement of tissue receptors for insulin may resolve this question. In No, 5442, which died at 257 days, glucose concentrations were above $12 \mathrm{mmol} / \mathrm{l}$ and rising from 140 days of age, but insulin secretion did not increase before death. This lamb appeared to have classical Type 1 diabetes which is caused by a pancreatic $\beta$-cell failure.

\section{Prolactin, FSH, LH and steroid hormones}

The secretory patterns of prolactin, FSH and LH were determined to examine the question of whether a lesion in the hypothalamic-pituitary-gonadal axis had occurred in the presence of high 
Table 3. Biochemical characteristics (mean \pm s.d.) of blood plasma from control $(\mathrm{N}=3)$ and transgenic $(\mathrm{N}=3)$ lambs

\begin{tabular}{|c|c|c|c|}
\hline Substance & Control & Transgenic & $\begin{array}{l}\text { Significance } \\
\qquad(t \text { test })\end{array}$ \\
\hline Calcium (mmol/l) & $2.32 \pm 0.59$ & $2.44 \pm 0.61$ & \\
\hline Phosphate (mmol/l) & $2.95 \pm 0.58$ & $2.88 \pm 0.69$ & \\
\hline Urea (mmol/1) & $6 \cdot 38 \pm 1.60$ & $6.13 \pm 2.37$ & \\
\hline Creatinine (mmol/1) & $56 \cdot 3 \pm 11 \cdot 5$ & $56 \cdot 6 \pm 14 \cdot 2$ & \\
\hline Glucose (mmol/1) & $4.7 \pm 0.5$ & $7 \cdot 9 \pm 2.2$ & $P=0.071$ \\
\hline Protein $(\mathrm{g} / \mathrm{l})$ & $57.7 \pm 2 \cdot 1$ & $62.4 \pm 2.7$ & $P=0.077$ \\
\hline Cholesterol* (mmol/l) & $1.30 \pm 0.05$ & $2.10 \pm 0.73$ & $P=0.13$ \\
\hline Triacylglyceride* $(\mathrm{mmol} / \mathrm{l})$ & $0.10 \pm 0.03$ & $0.21 \pm 0.05$ & $P=0.036$ \\
\hline $\mathrm{SAP}+$ (units/l) & $214 \pm 68$ & $159 \pm 49$ & $P=0.32$ \\
\hline AST (units/1) & $57.4 \pm 20 \cdot 6$ & $76.6 \pm 142 \cdot 1$ & \\
\hline ALT (units/t) & $5.20 \pm 3.91$ & $11.75 \pm 2.97$ & $P=0.082$ \\
\hline yGT- (units/1) & $92 \cdot 1 \pm 6 \cdot 4$ & $149 \cdot 3 \pm 7 \cdot 7$ & $P=0.0006$ \\
\hline Insulin (ng/ml) & $1.9 \pm 0.3$ & $12.4 \pm 1.4$ & $P=0.0002$ \\
\hline
\end{tabular}

Lambs were bled once/week until death. Parameters were measured on COBAS-BIO or SMAC-II analysers except for insulin which was estimated by radioimmunoassay.

Data from samples after $150(*), 100(\dagger)$, or $50(\ddagger)$ days of age only were analysed.

concentrations of circulating $\mathrm{GH}$. Transgenic animals expressing $\mathrm{GH}$ have reproductive problems (Hammer et al., 1984; Pursel et al., 1987, 1989) and it is known that puberty is delayed when females have insufficient bodyfat content (Foster, 1988; Frisch, 1988). FSH showed no difference in concentrations (Table 1) or in the manner of secretion during an intensive 26-h bleeding period (data not shown). The concentrations of prolactin, reflecting pulsatile secretion, are shown in Table 1 and appeared to be lower in transgenics than in controls for females (Nos 3902-3906) but higher for males (Nos 5442-5443) with greater peak amplitude (data not shown). LH values, which can indicate pituitary and reproductive status with respect to puberty, were not different between the lambs. Essentially there were 3 or more peaks of LH in each animal over the 26-h period (Fig. 3), leading to the conclusion that no lesion or negative feedback loop had appeared in the reproductive axis of transgenic lambs.

Testosterone measurements were used to assess the testicular response in male lambs to a challenge of gonadotrophin-releasing hormone $(\mathrm{GnRH})$ imposed at the end of the 26-h serial bleed (Fig. 4). Release of both LH and testosterone occurred. Although the testosterone response of the transgenic ram was lowest of the 4 rams tested, this could have been due to the fact that testicular growth, measured with an orchidometer, was delayed and remained at about $50 \%$ that of controls until death (Fig. 5; Table 4). Histological assessment of a testicular biopsy taken at 177 days showed that one-third of the tubules had begun meiosis, all cell types within the tubules from a single layer of Sertoli cells to spermatocytes were present, but no evidence of spermatogenesis or spermatozoa was found. The developmental stage was correct for testes of about $90 \mathrm{~g}$, but delayed for a ram of $39 \mathrm{~kg}$ bodyweight, suggesting that sexual development in the transgenic ram was retarded. There was no evidence that this was due to inadequate primary endocrine stimulation.

Progesterone was assayed in plasma samples throughout the life of the female lambs to assess. whether puberty occurred before death; neither of the transgenic lambs reached puberty or showed sign of ovarian follicular development at the time of death at 303 and 326 days, but both controls experienced luteal cycles from around 210 days of age.

\section{Thyroid hormones and metabolic rate}

The thyroid hormones, thyroxine and T3, fluctuated in concentration and were lower in transgenic females than controls; no differences were found between the males (Table 1). Lower thyroid 


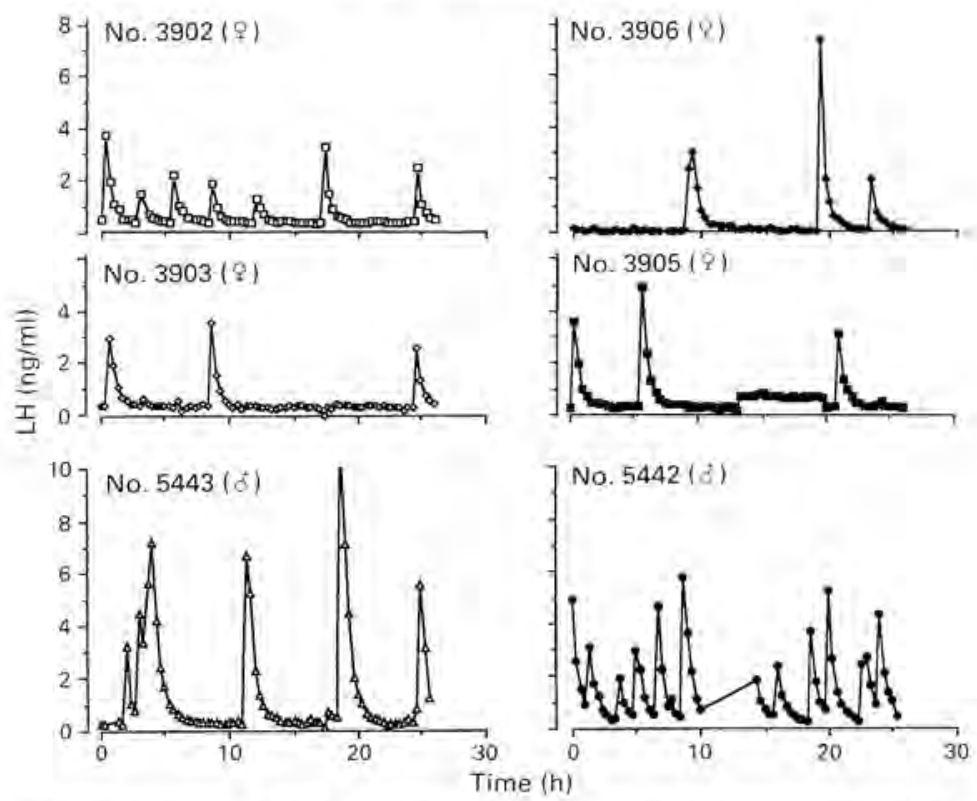

Fig. 3. LH plasma profiles in serially bled lambs. Blood was sampled every $20 \mathrm{~min}$ for $26 \mathrm{~h}$ from jugular catheters maintained in transgenic and control lambs. Filled symbols represent transgenic lambs, open symbols control lambs.
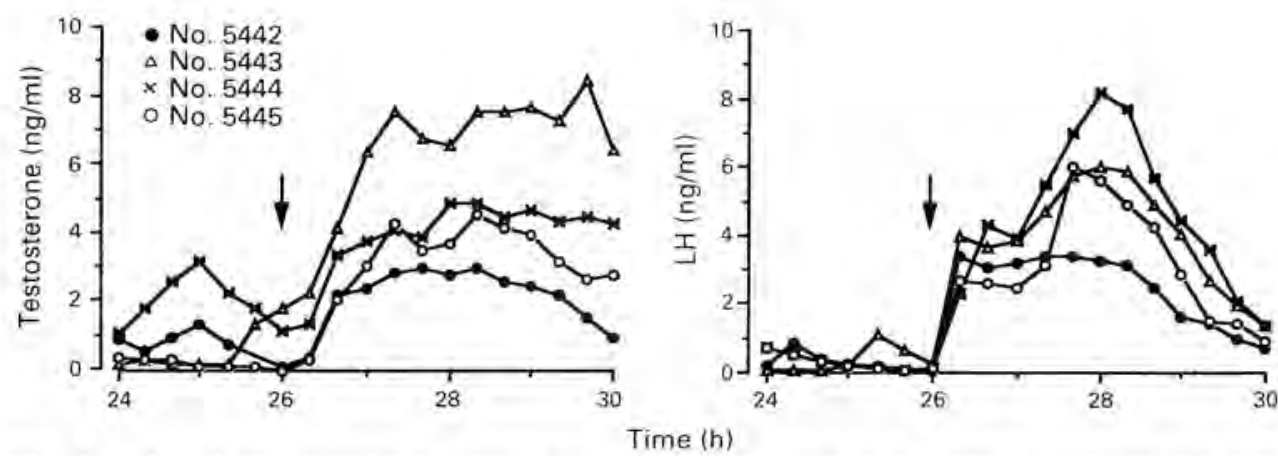

Fig. 4. LH and testosterone response to GnRH stimulation in transgenic and control ram lambs. GnRH $(250 \mu \mathrm{g})$ was given at the end of the 26 -h bleeding period and the lambs bled for a further $4 \mathrm{~h}$ at 20 -min intervals. Filled symbols represent transgenic lambs, open symbols control lambs.

hormone levels should decrease the basal metabolic rate (BMR) but the evidence for females showed that the BMR was increased by $30 \%$ and heat production by $20-50 \%$ (Graham \& Margan, 1988). The stimulation of free fatty acid (FFA) utilization by GH might contribute to this increase in BMR in the female transgenics, but experiments were not carried out with the males. Perhaps the greater metabolic activity and heat production, driven by the excess GH, insulin and IGF-1 concentrations, negatively influences thyroid function. We have not measured thyroid-stimulating hormone in samples from these animals.

Protein concentrations in plasma appeared slightly elevated $(P=0.077$. Table 3$)$ and this could be due to increased insulin, IGF-1 and glucose concentrations. Insulin and IGF-1 are known 


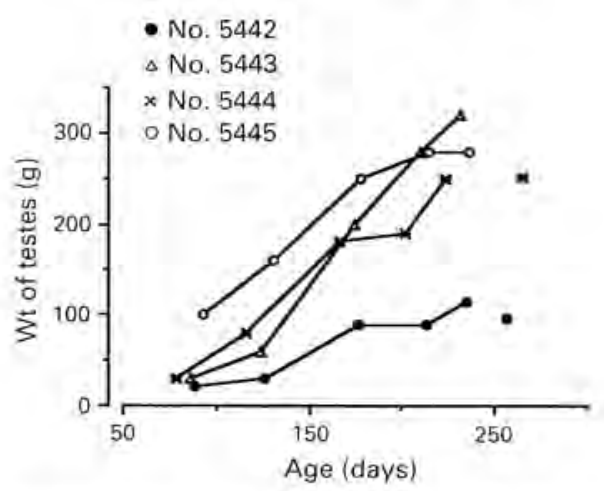

Fig. 5. Growth of testes in transgenic and control lambs. Mass was determined by manual comparison with a standardized set of orchids, except for the final points for Nos 5442 and 5444 that represent post-mortem weights. Filled symbols represent transgenic lambs, open symbols control lambs.

to increase both glucose and amino acid transport into the tissues, which results in increased metabolic activities including protein synthesis. Protein turnover and oxygen consumption were increased but protein synthesis was not significantly higher at the 5\% level (Oddy et al., 1988). Graham \& Margan (1988) also found that methane production and nitrogen retention were normal. These data suggest that MtsGH9 sheep would be useful for studying the controls over lipid and protein metabolism as they relate to growth and development.

\section{Biochemistry and pathology}

\section{Blood biochemical assays}

Certain enzymes appear in serum as a result of metabolic breakdown of cells and tissues and this can be used as an indicator of tissue disorder. The enzymes creatinine kinase (CPK), lactate dehydrogenase (LDH) and aspartate aminotransferase (AST) were routinely estimated in plasma using a COBAS-BIO analyser (F. Hoffman La Roche \& Co., Basle, Switzerland). Serum alkaline phosphatase (SAP), alanine aminotransferase (ALT) and gamma glutamyl transferase ( $\gamma$ GT), along with all other biochemical analyses presented in Table 3, were estimated on a Simultaneous Multichannel Analyser and Computer (SMAC-II, Technicon Equipment Pty Ltd, North Ryde, NSW, Australia). When possible, these blood analyses were carried out on samples collected weekly from control and transgenic lambs. When sample means of individual lambs were comparable between experimental groups by $t$ test, the probability values are indicated.

\section{Electrolytes and minerals}

There were no differences in plasma electrolytes (not shown) or bone mineral concentrations between the control and transgenic lambs (Table 3). The control lambs formed the basis of normal values and no assessment was carried out or adjustment made for species effects on any biochemical estimate. The levels of SAP, an indicator of osteoblast activity and bone deposition that is normally high in the young, appeared to be lower for MtsGH9 lambs after 100 days, suggesting a reduction in osteoblast activity (bone growth and mineralization) at that stage. However, with large variability this difference was not statistically significant. These various biochemical measurements do not explain why considerable bone deformations occur in transgenic pigs and sheep, accompanied 
by erosion of the articular surfaces, sinovitis and malposition of the distal extremities of the forelimbs (Pursel et al., 1989; Nancarrow et al., 1989). However, we recommend that studies of bone metabolism be part of any further work with transgenic livestock containing GH fusion genes.

\section{Kidney function}

The levels of plasma urea and creatinine, indicators of kidney function, were generally not different between transgenics and controls (Table 3), except for No. 548, when death was preceded for a 2-week period by greatly elevated concentrations of plasma urea $(>150 \mathrm{mmol} / \mathrm{l})$, creatinine $(>1000 \mathrm{mmol} / \mathrm{l})$, uric acid $(>0.1 \mathrm{mmol} / \mathrm{l})$ and bilirubin $(>3.0 \mu \mathrm{mol} / \mathrm{l})$. However, creatinine in all 3 and urea in 2 of the other transgenic lambs, also rose well above normal levels in the last week before death. During kidney failure, proteinuria is often accompanied by lower plasma protein levels, but in these lambs, the transgenics tended to have slightly higher concentrations of plasma protein despite necrosis and haemorrhage being found at autopsy (Nancarrow et al., 1989).

\section{Liver function}

Like the kidneys, livers from transgenic lambs were severely degenerated at autopsy. The enzyme $\gamma \mathrm{GT}$, an indicator of liver function, was significantly raised throughout the life of the animals while ALT tended to higher levels of activity (Table 3). In humans, $\gamma$ GT is particularly indicative of drug-induced damage and cirrhosis of the liver. In these sheep, the constant high levels of $\mathrm{GH}$ would act directly on the liver, perhaps causing a release of the enzymes, and culminating later in fatal degenerative effects. It is also possible that high $\gamma \mathrm{GT}$ activities result from damage to other tissues such as the kidney and pancreas; many tissues show degenerative change in transgenic animals (Nancarrow et al., 1989; Pursel et al., 1987, 1989). These plasma enzymes did not indicate that altered liver function was primarily responsible for the death of lamb No. 548, in that the activity of $\gamma$ GT remained within normal limits although that for ALT was raised to above 60 units/1 over the last week.

\section{Heart function}

CPK and LDH (data not shown), and AST (Table 3), are all indicators of heart function abnormalities which result in cellular enzymes being released into the blood. Plasma activities of these enzymes did not indicate any chronic heart problems except for No. 548. Over the last 2 weeks of life for this lamb, the activities of all enzymes were extremely high, AST $>400$ units/l, CPK $>10000$ units/l and LDH > 1000 units/1. In the other transgenic lambs, elevated enzyme activities were found only in the last samples. At autopsy it was noted that there was cardiomegaly (Table 4), some fibre hypertrophy and valvular endocarditis (Nancarrow et al., 1989). Similar effects were reported for transgenic pigs (Pursel et al., 1989).

\section{Carbohydrates and lipids}

$\mathrm{GH}$ has both glycogenolytic and lipolytic action and so it was not unexpected to find a trend to elevated plasma glucose $(P=0.071)$ and triacylglyceride $(P=0.036)$ concentrations (Table 3$)$. It appears that mobilization of lipolytic products occurred. In an environment of high $\mathrm{GH}$ stimulation, these metabolites may act as an energy source rather than a lipogenic source resulting in a reduction of fat content in the sheep (Graham \& Margan, 1988). Examination of the carcass revealed very little perirenal and mesenteric fat and the deposition of backfat around the twelfth rib was greatly reduced (Fig. 6) in a fashion identical to that in transgenic pigs (Pursel et al., 1989). Free fatty acids would be expected to increase in concentration with $\mathrm{GH}$-stimulated lipolysis and also 


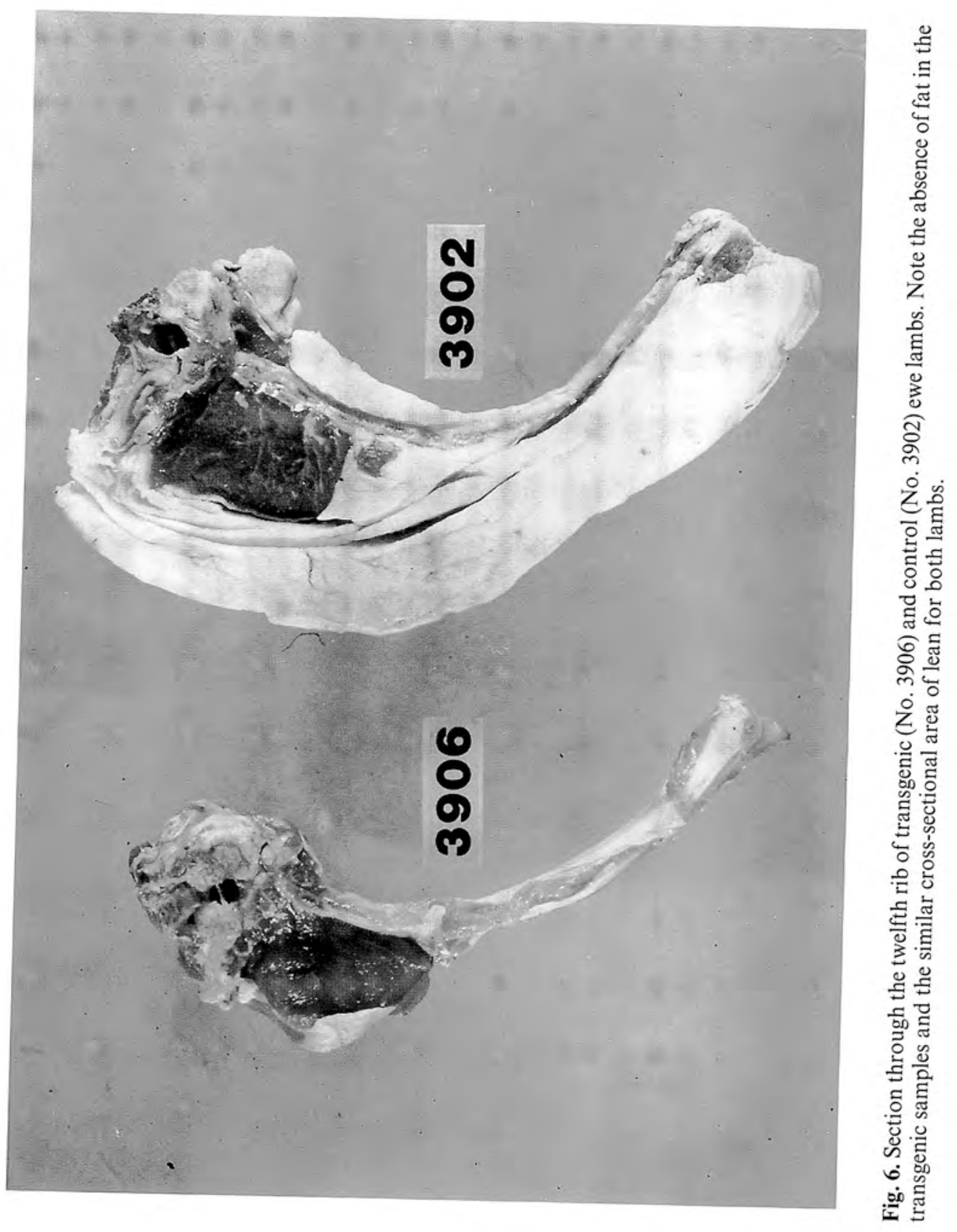


act as metabolic fuel, but concentrations were not determined. Insulin concentrations are generally elevated throughout the life of the transgenic lambs (Table 3 ) and this would possibly contribute to increased utilization of substrates by tissues leading to increased BMR and protein turnover.

\section{Organ growth}

The outcome of excess $\mathrm{GH}$ action in humans with acromegaly and in transgenic pigs and mice is the increased size of the visceral organs (Shea et al., 1987; Pursel et al., 1989). In transgenic mice containing the fusion gene, mouse metallothionein-rat GH, the liver and spleen were positively allometric, increasing in size proportionally faster than the body weight of the mice. This may occur due to direct action of the GH or its product, IGF-1. Visceromegaly was observed in MtsGH9 lambs (Table 4) with significant enlargement of the liver and kidneys. In addition the heart and lungs appeared enlarged. Transgenic pigs have been reported to have enlarged livers, heart, kidney, adrenal glands and thyroid (Pursel et al., 1989). In contrast to mice carrying the same fusion gene, therefore, the visceral organs of transgenic livestock increased in size while skeletal and body size remained the same.

Table 4. Visceromegaly in transgenic lambs, expressed as a percentage of body weight

\begin{tabular}{|c|c|c|c|c|c|c|c|}
\hline \multirow[b]{2}{*}{$\begin{array}{l}\text { Sheep no. } \\
\text { Gender } \\
\text { Age (days) } \\
\text { Weight (kg) }\end{array}$} & \multicolumn{3}{|c|}{ Control } & \multicolumn{3}{|c|}{ Transgenic } & \multirow[t]{2}{*}{$\begin{array}{c}\text { Significance } \\
\quad(t \text { test })\end{array}$} \\
\hline & $\begin{array}{c}3902 \\
9 \\
333 \\
48 \cdot 8\end{array}$ & $\begin{array}{c}3903 \\
9 \\
329 \\
39 \cdot 6\end{array}$ & $\begin{array}{c}5444 \\
0 \\
264 \\
58.0\end{array}$ & $\begin{array}{c}3905 \\
6 \\
97 \\
303 \\
37 \cdot 4\end{array}$ & $\begin{array}{c}3906 \\
9 \\
9 \\
326 \\
29 \cdot 0\end{array}$ & $\begin{array}{c}5442 \\
5 \\
257 \\
43 \cdot 4\end{array}$ & \\
\hline $\begin{array}{l}\text { Liver } \\
\text { Kidneys } \\
\text { Lung } \\
\text { Brain } \\
\text { Heart } \\
\text { Testes }\end{array}$ & $\begin{array}{l}1.23 \\
0.22 \\
0.82 \\
0.14 \\
0.29 \\
-\end{array}$ & $\begin{array}{l}1.34 \\
0.36 \\
1.04 \\
0.18 \\
0.40\end{array}$ & $\begin{array}{l}1.32 \\
0.20 \\
0 \cdot 64 \\
0 \cdot 10 \\
0.32 \\
0 \cdot 44\end{array}$ & $\begin{array}{l}2.01 \\
1.00 \\
0.92 \\
0.21 \\
0.48 \\
-\end{array}$ & $\begin{array}{l}2.07 \\
0.82 \\
2.23 \\
- \\
- \\
-\end{array}$ & $\begin{array}{r}3.00 \\
0.52 \\
1.57 \\
-\quad \\
0.41 \\
0.22\end{array}$ & $\begin{array}{l}P=0.03 \\
P=0.025 \\
P=0.14\end{array}$ \\
\hline
\end{tabular}

\section{Discussion}

Transgenic lambs containing various sMtsGH fusion genes have been produced by pronuclear microinjection. Only the MtsGH9 gene is expressed constitutively in several tissues at a high level, resulting in excessive concentrations of $\mathrm{GH}$ circulating in the plasma. In contrast, the same construct in mice expresses minimally and requires zine to raise $\mathrm{GH}$ levels to obtain a phenotypic response.

We have proposed a generalized outcome of hypersomatotrophinaemia in transgenic sheep and this is shown in Fig. 7. Both glycogenolysis and IGF-1 secretion are direct, measurable effects resulting in raised plasma concentrations of glucose and IGF-1, Insulin secretion increases in response to glucose and this hormone together with IGF-1 stimulates glucose and amino acid transport into the tissues. It is possible that $\mathrm{GH}$ prevents glucose reforming glycogen in the liver and stimulates its catabolism thus increasing oxygen consumption, BMR, protein turnover and heat production. While insulin may promote a positive nitrogen balance by increasing the tissue utilization of glucose and amino acids, a concomitant increase in protein catabolism negates this. It may be for this reason that the transgenic sheep have not grown faster, but as they have similar bodyweight and less fat, they probably have a greater protein content. Of course, much of this difference may be due to the increased size of the viscera and not the skeletal muscle, as can be seen in Fig. 6. 


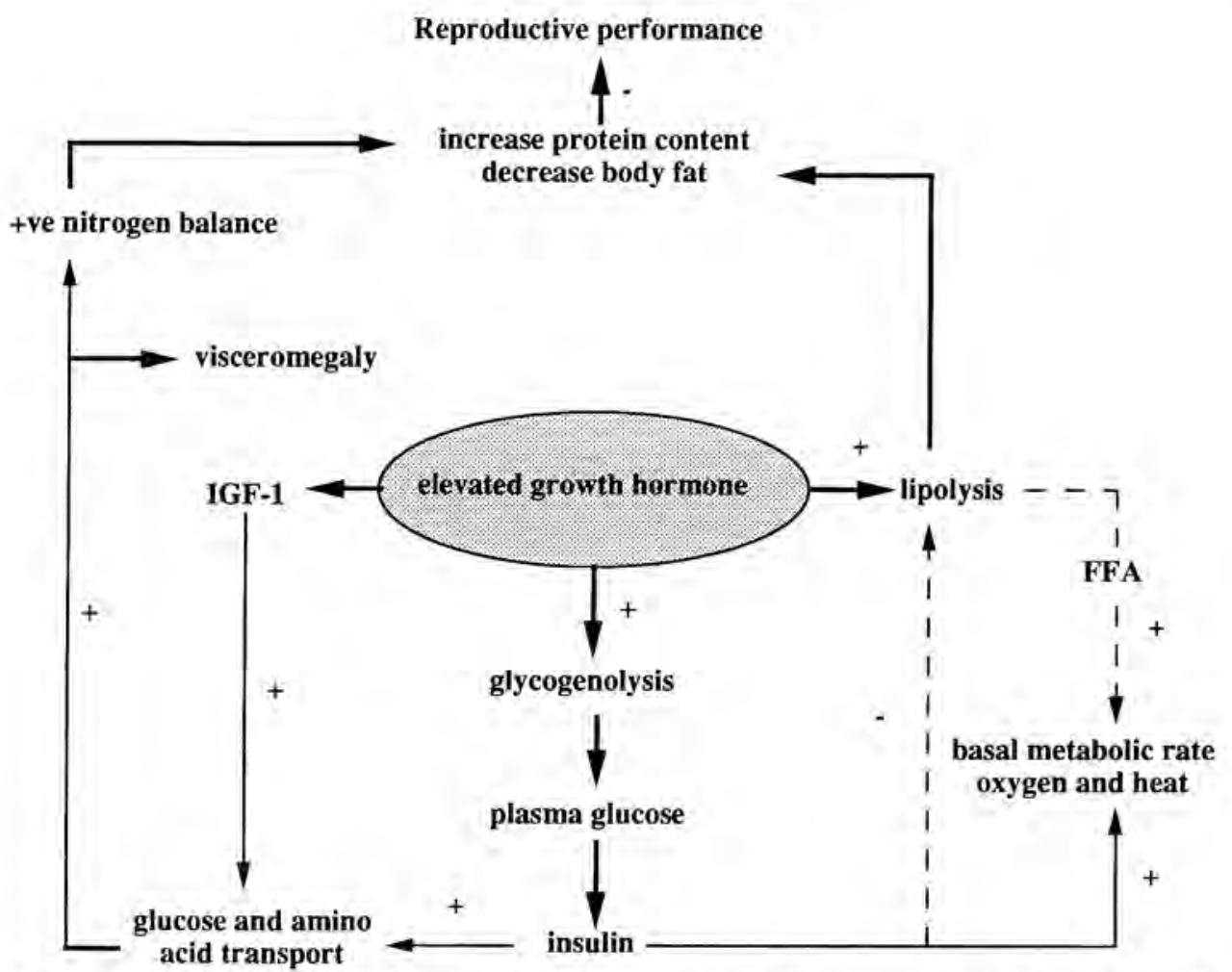

Fig. 7. Generalized proposal for metabolic regulation in transgenic sheep expressing the MtsGH9 fusion gene.

The poor visual condition of transgenic sheep provided the first evidence of the lipolytic or antilipogenic action of GH. Spinal and pelvic bones protruded, very little fat was found on the carcass and tritiated water measurements showed a significant increase in total body water and decrease in fat (Graham \& Margan, 1988). This has been noted in all transgenic livestock expressing $\mathrm{GH}$ genes from various sources. The lipolytic action of $\mathrm{GH}$ should result in elevated free fatty acids and studies have demonstrated this effect over the short-term in sheep (Manns \& Boda, 1965; Bassett \& Wallace, 1966). Lipolysis may also result in an increase in circulating triacylglycerides, but the results generated in this work need confirmation. Whether GH stimulates the utilization of other lipolytic products, particularly the free fatty acids, as energy and heat sources within skeletal tissues would depend also on their production rate from ruminal and intestinal fatty acid synthesis and the proportion undergoing lipogenesis. It is more likely that enhanced oxidation of free fatty acid and glucose accounts for the differences in BMR. We suggest that lipogenic substances are synthesized only to be used as metabolic fuel under these unique hormonal conditions. The net outcome of these biochemical changes is that the lambs grow with an increased protein content and decreased fat content. This may be an excellent result for the lamb producer but the other physiological changes described negate this advantage.

It has been previously reported that hypersomatotrophic mice, pigs and sheep suffer from restricted reproductive development, Gilts fail to exhibit oestrus and transgenic lines are established through male founders (Pursel et al., 1989), although boars express a low libido. Transgenic female mice expressing the human or rat GH gene are generally infertile (Hammer et al., 1984) but mice expressing the human GH-releasing factor gene remain fertile (Hammer et al., 1985a). The latter group have high plasma $\mathrm{GH}$ concentrations and increased body size, but the GH has been secreted 
only by the pituitary somatotrophs. This evidence suggests that interference in reproductive physiology may be due, in part at least, to direct effects of the GH on gonadal tissues. However, our data that MtsGH9 mice can mate and give birth normally may mean that there is also a species effect involved at this level. Puberty in MtsGH9 sheep was delayed and the ewes died before their first ovulatory cycle. There was no evidence to indicate whether these sheep would have ovulated had they survived. The testes of the transgenic male developed at about half the normal rate but appeared capable of producing spermatozoa had the ram lived. All MtGH9 sheep appeared in poor condition and, with their low fat content, presented a syndrome somewhat analogous to that of human anovulation induced by anorexia nervosa or intensive athletic training (Frisch, 1988). It is well known that puberty does not occur until a certain body size is attained, below which the hypothalamic pulse generator is too sensitive to oestradiol negative feedback (Foster, 1988). However, the LH pulses found in these transgenic sheep were similar to controls in frequency and amplitude and the LH response to GnRH in the male appeared normal. Frisch (1988) has proposed that body fat content is of importance in the onset of puberty and resumption of ovarian cycles in anovulatory women. Lucy et al. (1989) have shown that feeding calcium soaps of long-chain fatty acids stimulates ovarian activity in lactating dairy cows by increasing the number of follicles moving into higher classes, a result that was not completely explained by the positive effects of energy balance. While the nature of the biochemical factor which modulates the GnRH pulse generator is speculative (Foster, 1988), our data indicate that reproduction in these transgenic sheep is not inhibited at this level. Rather, it is suggested that the unusual concentrations of metabolic hormones and metabolites have a direct effect on metabolism of the gonads which restricts their appropriate growth and development.

Transgenic animals expressing GH may prove a useful model for examining many physiólogical processes. Their use as productive entities will not be possible without control over the expression of the transgene. At the same time we must remain aware of the ethical problems of producing physiologically unfit animals for experimentation.

We thank Dr B. Purser for the zinc-deficient diet; Dr M. Wong for progesterone antiserum; Dr P. Mattner for help in estimating testicular size and function; I. Hazelton for advice and assistance with animal husbandry; N. Rigby and C. Townrow for screening sheep and carrying out gene expression analyses; T. Reddan, K. Lewis, G. Hardwicke, W. Ward, E. Fleck, P. Carroll, J. Downing, R. Newman and A. Rintoul for skilled advice and technical assistance in carrying out various assays; Dr N. Graham and Dr H. Oddy for data on energy metabolic studies; and Dr R. Dixon and Dr B. Farquharson for pathology services.

\section{References}

Bassett, J.M. \& Wallace, A.L.C. (1966) Short-term effects of ovine growth hormone on plasma glucose, free fatty acids and ketones in sheep. Metabolism 15, 933-944.

Clark, A.J., Bessos, H., Bishop, J.O,, Brown, P., Harris, S., Lathe, R., McClenaghan, M., Prowse, C., Simons, J.P., Whitelaw, C.B.A. \& Wilmut, I. (1989) Expression of Human anti-hemophilic factor IX in the milk of transgenic sheep. Bio/lechnology 7, 487-492.

Costantini, F. \& Lacy, E. (1981) Introduction of a rabbit $\beta$-globin gene into the mouse germ line. Nature, Lond. 294, 92-94.

Daughaday, W.H., Parker, K.A., Borowski, S., Trivedi, B. \& Kapadia, M. (1982) Measurement of somatomedinrelated peptides in fetal, neonatal, and maternal rat serum by insulin-like growth factor (IGF) I radio- immunoassay, IGF-II radioreceptor assay (RRA). and multiplication-stimulating activity RRA after acid-ethanol extraction. Endocrinology 110, 575-581.

Ebert, K.M., Low, M.J., Overstrom, E.W., Buonomo, F.C, Baile, C.A., Roberts, T.M., Lee, A., Mandel, G. \& Goodman, R.H. (1988) A Moloney MLV-rat somatotropin fusion gene produces biologically active somatotrophin in a transgenic pig. Molec, Endocrinol. 2, 277-283.

Foster, D.L. (1988) Puberty in the female sheep. In The Physiology of Reproduction, vol. 2, pp. 1739-1762. Eds E. Knobil \& J. D. Neill. Raven Press, New York.

Frisch, R.E. (1988) Fatness and fertility. Scientific American 258, 70-78.

Gordon, J.W., Scangos, G.A., Plotkin, D., Barbosa, J.A. \& Ruddle, F.H. (1980) Genetic transformation of 
mouse embryos by microinjection of purified DNA. Proc. natn. Acad. Sci. USA 77, 7380-7384.

Graham, N.McC. \& Margan, D.E. (1988) Energy and nitrogen utilization in growth hormone transgenic sheep. Proc. Nutr. Soc, Aust, 13, 151 (abstr.).

Hammer, R.E., Palmiter, R.D. \& Brinster, R.L. (1984) Partial correction of murine hereditary growth disorder by germline incorporation of a new gene. Nature, Lond. 311, 65-67.

Hammer, R.E., Brinster, R.L., Rosenfeld, M.G., Evans, R.M. \& Mayo, K.E. (1985a) Expression of human growth hormone-releasing factor in transgenic mice results in increased somatic growth. Nature, Lond. $315,413-416$.

Hammer, R.E., Pursel, V.G., Rexroad, C.E., Jr, Wall, R.J., Bolt, D.J., Ebert, K.M., Palmiter, R.D. \& Brinster, R.L. (1985b) Production of transgenic rabbits, sheep and pigs by microinjection. Nature, Lond. $315,680-683$.

Hammer, R.E., Pursel, V.G., Rexroad, C.E., Jr, Wall, R.J., Bolt, D.J., Palmiter, R.D, \& Brinster, R.L. (1986) Genetic engineering of mammalian embryos. J. Anim. Sci. 63, 269-278.

Lucy, M.C., Thatcher, W.W., Michel, F.J. \& Staples, C.R. (1989) Effect of dietary calcium soaps of long chain fatty acids (Megalac) on plasma prostaglandin F metabolite (PGFM), energy balance, and follicular populations in early postpartum dairy cattle. J. Dairy Sci. 72, Suppl. 1, Abstr. 942.

Manns, J.G. \& Boda, J.M. (1965) Eflects of ovine growth hormone and prolactin on blood glucose, serum insulin. plasma nonesterified fatty acids and amino nitrogen in sheep. Endocrinology 76, 1109-1114.

Miller, K.F., Bolt, D.J., Pursel, V.G., Hammer, R.E., Pinkert, C.A., Palmiter, R.D. \& Brinster, R.L. (1989) Expression of human or bovine growth hormone gene with a mouse metallothionein-1 promoter in transgenic swine alters the secretion of porcine growth hormone and insulin-like growth factor-1.J. Endocr. 120, $481-488$.

Murray, J.D., Nancarrow, C.D., Marshall, J.T., Hazelton, I.G. \& Ward, K.A. (1989) Production of transgenic Merino sheep by microinjection of ovine metallothionein-ovine growth hormone fusion genes. Reprod. Fert. Dev, 1, 147-155,

Nancarrow, C.D., Shanahan, C.M., Byrne, C., Marshall, J.T.A., Murray, J.D., Hazelton, I.G., Rigby, N.W., Townrow, C.A. \& Ward, K.A. (1988a) Controlled production of sheep growth hormone in transgenic mice and sheep. Proc. IIth Int. Congr. Animal Reprod. \& A.I. Dublin, Vol. 4, No. 478.

Nancarrow, C.D., Ward, K.A. \& Murray, J.D. (1988b) The future for transgenic livestock in Australian agriculture. Aust. J. Biotech. 2, 39-44.

Nancarrow, C.D., Shanahan, C.M., Dixon, R.J., Farquharson, B., Ward, K.A., Murray, J.D. \&
Marshall, J.T.A. (1989) Growth hormone expression and effects in transgenic sheep. In Bioleclinology in Growth Regulation, p. 265 (abstr.). Eds R. B. Heap, C. G. Prosser \& G. E. Lamming. Butterworth Scientific, London.

Oddy, V.H., Warren, H.M. \& Ewoldt, C.L. (1988) Elevated muscle protein breakdown in growth hormone transgenic sheep. Proc. Nutr. Soc. Aust 13,159 (abstr.).

Owens, P.C., Johnson, R.J., Campbell, R.G. \& Ballard, F.J. (1990) Growth hormone increases insulin-like growth factor-I (IGF-I) and decreases IGF-II in plasma of growing pigs. J. Endocr. 124, 269-275.

Palmiter, R.D., Brinster, R.L., Hammer, R.E., Trumbauer, M.E., Rosenfeld, M.G., Birnberg, N.C. \& Evans, R.M. (1982) Dramatic growth of mice that develop from eggs microinjected with metallothioneingrowth hormone fusion genes. Nature, Lond. $\mathbf{3 0 0}$, 611-615.

Palmiter, R.D., Norstedt, G., Gelinas, R.E., Hammer, R.E. \& Brinster, R.L. (1983) Metallothionein-human $\mathrm{GH}$ fusion genes stimulate growth of mice. Science, NY 222, 809-814.

Pursel, V.G., Rexroad, C.E., Jr, Bolt, D.J., Miller, K.F., Wall, R.J., Hammer, R.E., Pinkert, C.A., Palmiter, R.D. \& Brinster, R.L. (1987) Progress on gene transfer in farm animals. Vel. Immunol. Immumopath. 17, 303-312.

Pursel, V.G., Pinkert, C.A., Miller, K.F., Bolt, D.J., Campbell, R.G., Palmiter, R.D., Brinster, R.L. \& Hammer, R.E. (1989) Genetic engineering of livestock. Science, NY 244, 1281-1288.

Rexroad, C.E., Jr \& Pursell, V.G. (1988) Status of gene transfer in domestic animals. Proc. 11th Int. Congr. Animal Reprod. \& A.I, Dublin, Vol. 5, 29-35.

Rexroad, C.E., Jr, Hammer, R.E., Bolt, D.J., Mayo, K.M., Frohman, L.A., Palmiter, R.D. \& Brinster, R.L. (1989) Production of transgenic sheep with growth regulating genes. Molec. Reprod. Devel. 1, I64-I69.

Shanahan, C.M., Rigby, N.W., Murray, J.D., Marshall, J.T., Townrow, C.A., Nancarrow, C.D. \& Ward, K.A. (1989) Regulation of expression of a sheep metallothionein la-sheep growth hormone fusion gene in transgenic mice. Molec. cell. Bial. 9, 5473-5479.

Shea, B.T, Hammer, R.E. \& Brinster, R.L. (1987) Growth allometry of the organs in giant transgenic mice. Endocrinology 121, 1924-1930.

Simons, J.P., Wilmut, I., Clark, A.J., Archibald, A.L., Bishop, J.O. \& Lathe, R. (1988) Gene transfer into sheep. Bio/technology 6, 179-182.

Ward, K.A., Nancarrow, C.D., Murray, J.D., Shanahan, C.M., Byrne, C.R., Rigby, N.W., Townrow, C.A., Leish, Z., Wilson, B.W., Graham, N.McC., Wynn, P.C., Hunt, C.L. \& Speck, P.A. (1990) The current status of genetic engineering of domestic animals. J. Dairy Sci. 73, 2586-2592. 